\title{
CAPITAL STRUCTURE AND BANK PERFORMANCE OF ISLAMIC AND COMMERCIAL IN YEMEN
}

\author{
Samer Ahmed Ali Assirri ${ }^{1} \square$, Dr. C.K. Hebbar ${ }^{2}$ \\ ${ }^{1}$ Research Scholar, Department of Studies and Research in Commerce, Mangalore University, India. \\ ${ }^{2}$ Associate Professor and Research Guide, Department of Commerce, Mangalore University, India.
}

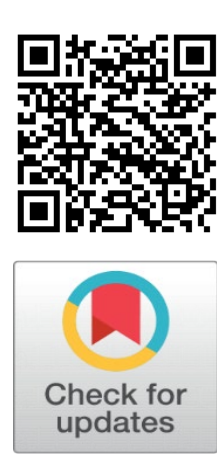

Received 17 November 2021

Accepted 5 December2021

Published 31 December2021

\section{CorrespondingAuthor}

Samer Ahmed Ali Assirri, malshawesh37m@gmail.com

DOI

10.29121/granthaalayah.v9.i12.2021 4411

Funding: This research received no specific grant from any funding agency in the public, commercial, or not-for-profit sectors.

Copyright: (C) 2021 The Author(s). This is an open access article distributed under the terms of the Creative Commons Attribution License, which permits unrestricted use, distribution, and reproduction in any medium, provided the original author and source are credited.

\section{ABSTRACT}

This study aims to examine the impact of capital structure on bank performance. This research verified the existence of several relationships between capital structure as measured by LAR, EAR, and Total Debt ratio on bank's performance as measured by ROA and ROE, EPS, and NPM. Using the panel data of bank from 2010 to 2019, In Islamic banks, the results of the present study revealed that the contributions of the capital structure to ROA were significant. This result was in line with the findings of the past studies. For instance, El-Chaarani and El-Abiad (2019) found that positive and significant impacts of short-term debt and total debt on the return on equity of the banking sector in Middle East region, a negative and significant impacts of short-term debt and total debt on the return on assets, and a positive impact of long-term debt on the return on assets ratio. In commercial banks sector the regression analysis revealed that the contributions of the three independent variables to the EPS were non-significant. Also, the contributions of the total debt and LAR to the independent variables ROE were significant. In contrast, the contribution of the EAR to the independent variable ROE was non-significant. Moreover, the contribution of the LAR to NPM was significant. Also, the contributions of the EAR and the total debt to NPM were non-significant. Furthermore, the contributions of the LAR and EAR to ROA were significant. In contrast, the contribution of the total debt to ROA was non-significant. In general, the contributions of the LAR and EAR to ROA were significant.

Keywords: Capital Structure, Performance, Total Debt, LAR, EAR, ROE, ROA, And EPS.

\section{INTRODUCTION}

Banks are essential in economic life because they are the foundation of the modern financial system, and international trade cannot be imagined without them. Banking systems are regarded as one of the most important inventions of modern society due to the primary role in bridging the gap between depositors, who form the money supply side of the banking system, and borrowers, who include the demand side for these funds. The banking system is a critical mechanism for collecting savings, converting them into investments, attracting foreign investments, and directing them to the most efficient, productive, and profitable projects.

The banking system's role in economic development is emphasized by providing credit to finance capital formation, and this will only occur as banks' ability to create credit that exceeds their cash reserves and paid-up capital, as well as various deposits resulting from current cash savings, or savings from previous earnings, improve. 
Financial performance is one of the most basic and necessary guarantees for the growth and continuity of businesses in all sectors, whether productive or service-oriented, such as traditional and Islamic banking institutions. The liabilities side of the balance sheet is represented by the financing structure in the financial statements, which includes equity (internal financing), long-term liabilities (external funding), and current liabilities. Companies seek to reduce costs and increase profits by managing the financing structure, as corporate finance necessitates a balance of internal and external financing.

The measurement of the bank's financial performance serves as the foundation for investment and financing decisions. Investors are interested in evaluating the bank's performance to determine the management's success in applying their capital, which represents equity. On the other hand, Debtors evaluate the performance of the interest rate report, which serves as their fixed return. Longterm financing options include equity and share issues, long-term loans, and debentures. As a result, the bank must comprehend the capital structure. The capital structure refers to the method, and sources of financing, Total debt, Total Liabilities to Total Assets Ratio (LAR), and Equity to Total Assets Ratio (ETAR) will be used to calculate capital structure (EAR).

\section{OBJECTIVE OF STUDY}

1) To identify the relationship between capital structure and bank's performance of of Islamic and commercial Bank in Yemen.

2) To identify the moderation effect of bank's size, growth opportunities and bank's age on the relation between capital structure and performance of Yemen Bank for Reconstruction and Development.

\section{RESEARCH HYPOTHESES}

(Ho1): Capital structure does not have statistically significant effects of Islamic bank performance in Yemen.

(Ho1): Capital structure does not have statistically significant effects of commercial bank performance in Yemen.

(H02): Banks' size, Growth opportunities and Banks' age does not have a statistically significant moderation role in the relation between capital structure and bank's performance of Islamic and commercial Bank in Yemen.

\section{RESEARCH METHODOLOGY}

The current study makes use of secondary data spanning the years 2010-2019. An examination of the correlation coefficient, the regression coefficient, the variance, and the standard deviation for the research variables Pearson The correlation coefficient will be calculated to determine the magnitudes and directions of the correlations between the independent and dependent variables. The regression analysis will be used to assess the impact of capital structure on bank performance. The Islamic and commercial banks in Yemen will be the dependent variable in the regression equation.

$$
\text { Y_1=Constant+ } \beta \_1 \text { X_1(it) + } \beta \_2 X \_2(i t)+\beta \_3 X \_3(i t)+\beta \_4 \text { X_4(it) +Error }
$$




\section{LITERATURE REVIEW}

Ali (2018) determined the factor affecting the profitability in a sample of seventeen conventional and five Islamic banks in Pakistan during the period 2008 2012. Return on Equity and Return on Asset were selected to represent the profitability (dependent variables) of Islamic and conventional banks in Pakistan. Whereas Credit Risk, Efficiency, Capitalization, Liquidity, Bank Size, Economic Performance, Inflation and a dummy variable were selected as independent variables. Panel Data analysis revealed: (1) Liquidity does not significantly related to profitability for both types of banks; (2) all the independent variables do not significantly relate to dependent variables for all the type of banks, (3) the impact of credit risk, capitalization, and the efficiency on profitability are more significant for conventional banks than Islamic banks

Meero (2015) identified the similarity of capital structure between Conventional and Islamic banks; and to investigate the relationship between capital structure and performance of Islamic and Conventional Banks in Gulf Countries (GC). The sample consisted of sixteen GC Banks (8 Islamic Banks and 8 Conventional Banks) over the period 2005-2014. Return on equity and return of asset have been used as performance indicators (dependent variables). Equity to total assets, total debt to total assets, debt to equity ratios and size of the bank have been used as capital structure indicators (independent variables). Data analysis (t-test, descriptive and regression analysis) revealed: (1) a similarity of capital structure of Islamic banks and Conventional banks in Gulf Countries; (2) return of asset significantly and negatively related to financial leverage and a positively related to equity to assets ratio in Islamic and Conventional banks; and (3) bank size has a positive relationship with return on equity and return of asset as performance measures in Islamic and Conventional banks

Kalash (2019) conducted his study to deal with a comparison of the capital structure of Islamic and traditional banks in Turkey in addition to investigate the effect of the debt ratio on the performance of these banks, as a comparative study was conducted between 5 Islamic banks and 11 traditional banks for a period of time extending from 2008 to 2017. The results revealed that the debt ratio has a positive and significant effect on the performance of Islamic banks, as the rate of return on total assets increases, and the rate of return on property rights as a result of the increase in the debt ratio. On the other hand, it was found that the debt ratio negatively affects the performance of traditional banks, as the rate of return on total assets decreases as a result of the high debt ratio of conventional banks. The results of the research are generally consistent with the theory of balance between the benefits and costs of debt, where the costs of debt (agency costs associated with debt and bankruptcy costs) are relatively low for Islamic banks within the framework of the balance theory, and therefore the high debt ratio of these banks will contribute to enhancing their performance as a result of the decline relative to costs.

Sheikh and Qureshi (2017) explored the determinants of capital structure of Islamic and conventional commercial banks from Pakistan. This study aimed to answer the following question: How conventional commercial banks and Islamic commercial banks choose their own capital structures. As well as what are the most important factors affecting the choice of capital structure? Financial reports and secondary data were used for banks listed on the Karachi Stock Exchange. Panel data were used to measure the regression and the relationship between the variables for the banks under the head from 2004 to 2014. The results of the study showed that traditional commercial banks are more used than Islamic commercial banks, as they 
are more profitable and have a fairly secure income. Islamic commercial banks, however, have relatively stable operating assets and growth in total assets compared to conventional commercial banks. The results also indicated that the profitability, growth and tangible capacity variables have a negative impact on the capital structure while the size of the bank and the fluctuations in profits has positive effects on capital structure. The study also pointed out that conventional banks and Islamic banks have their own ways of choosing capital.

\section{EMPIRICAL RESULT}

The Pearson product moment correlation coefficients were used to represent the relationship between the main independent variables (I.e., Total Debt, LAR, and EAR) and the dependent variables (ROA, ROE, NPM, EPS). Table 1 shows the correlation matrix that illustrates the interrelationships among the research variables.

\begin{tabular}{|c|c|c|c|c|c|c|c|c|}
\hline & ROE & ROA & NPM & EPS & Total debt & LAR & Kurtosis & Skewness \\
\hline ROE & 1 & & & & & & 1.197 & -0.605 \\
\hline ROA & $.447^{* *}$ & 1 & & & & & 0.564 & 0.566 \\
\hline NPM & $.929^{* *}$ & $.653^{* *}$ & 1 & & & & 0.249 & -0.735 \\
\hline EPS & 0.062 & $-.539^{* *}$ & -0.191 & 1 & & & -1.054 & -0.03 \\
\hline Total debt & $-.292^{*}$ & $-.437^{* *}$ & $-.476^{* *}$ & $.456^{* *}$ & 1 & & -1.388 & 0.52 \\
\hline LAR & $.337^{*}$ & $.940^{* *}$ & $.560^{* *}$ & $-.511^{* *}$ & $-.325^{*}$ & 1 & 0.148 & 0.115 \\
\hline EAR & $.438^{* *}$ & $.983^{* *}$ & $.659^{* *}$ & $-.540^{* *}$ & $-.601^{* *}$ & $.791^{* *}$ & -0.231 & 0.983 \\
\hline
\end{tabular}

It was observed that the total debt negatively and significantly related to ROE $(\mathrm{r}-.292 ; \mathrm{p}<.05)$, NPM ( $\mathrm{r}=-.476 ; \mathrm{p}<.01)$, and ROA ( $\mathrm{r}=-.437 ; \mathrm{p}<.01)$. In contrast, the total debt positively and significantly related to EPS $(\mathrm{R}=.456 ; \mathrm{p}<.01)$. LAR positively and significantly related to ROA ( $\mathrm{r}=.940 ; \mathrm{p}<.01)$, NPM $(\mathrm{r}=.560 ; \mathrm{p}<.01)$, and ROE $(\mathrm{r}=.337, \mathrm{p}<.05)$. In contrast, LAR negatively and significantly related to EPS ( $\mathrm{r}=-.511$; $\mathrm{p}<.01)$. EAR positively and significantly related to ROE $(\mathrm{r}=.438 ; \mathrm{p}<.01)$, ROA ( $\mathrm{r}=.983$; $\mathrm{p}<.01)$, and NPM $(\mathrm{r}=.659 ; \mathrm{p}<.01)$. In contrast, EAR negatively and significantly related to EPS ( $\mathrm{r}=-.540 ; \mathrm{p}<.01)$.

Multiple linear regression analysis was conducted to investigate the relative contribution of the predictors (independent variables) to the dependent variable, EPS. The model summary revealed that the model of the three independent variables explained $48 \%$ of the variance in EPS (R2 =.48). Results of ANOVA revealed that the model of total debt, LAR, and EAR was significantly predictor of EPS (Table 2).

\begin{tabular}{|c|c|c|c|c|c|c|}
\hline \multicolumn{7}{|c|}{ Table 2 Summary Results of ANOVA } \\
\hline & Model & Sum of Squares & df & Mean Square & $\mathbf{F}$ & Sig. \\
\hline 1 & Regression & 142.071 & 3 & 47.357 & 9.238 & .000 \\
\hline & Residual & 235.803 & 46 & 5.126 & & \\
\hline & Total & 377.874 & 49 & & & \\
\hline
\end{tabular}

As we can see in Table 4, the contributions of the independent variables to the EPS were non-significant. 


\begin{tabular}{|c|c|c|c|c|c|c|c|c|}
\hline \multirow{2}{*}{\multicolumn{2}{|c|}{ Model }} & \multirow{2}{*}{$\begin{array}{c}\text { Unstandardize } \\
\text { d Coefficients } \\
\text { B }\end{array}$} & & \multirow{2}{*}{$\begin{array}{c}\text { Standardized } \\
\text { Coefficients } \\
\text { Beta }\end{array}$} & \multirow[t]{2}{*}{$\mathbf{t}$} & \multirow[t]{2}{*}{ Sig. } & \multicolumn{2}{|c|}{$\begin{array}{l}\text { Collinearity } \\
\text { Statistics }\end{array}$} \\
\hline & & & $\begin{array}{l}\text { Std. } \\
\text { Error }\end{array}$ & & & & Tolerance & VIF \\
\hline \multirow[t]{4}{*}{1} & $\begin{array}{l}\text { (Const } \\
\text { ant) }\end{array}$ & -0.314 & 0.76 & & -0.413 & & & \\
\hline & $\begin{array}{l}\text { Total } \\
\text { debt }\end{array}$ & 0.108 & 0.056 & 0.294 & 1.921 & 0.859 & 0.577 & 1.732 \\
\hline & LAR & -2.269 & 1.146 & -0.397 & -1.981 & 0.515 & 0.338 & 2.96 \\
\hline & EAR & -0.126 & 0.552 & -0.054 & -0.227 & 0.475 & 0.241 & 2.147 \\
\hline
\end{tabular}

Further, Multiple linear regression analysis was conducted to investigate the relative contribution of the predictors (independent variables) to the dependent variable, ROE. The model summary revealed that the model of the three independent variables explained $69 \%$ of the variance in ROE (R2 =.69). Results of ANOVA revealed that the model of total debt, LAR, and EAR was significantly predictor of ROE (Table 4).

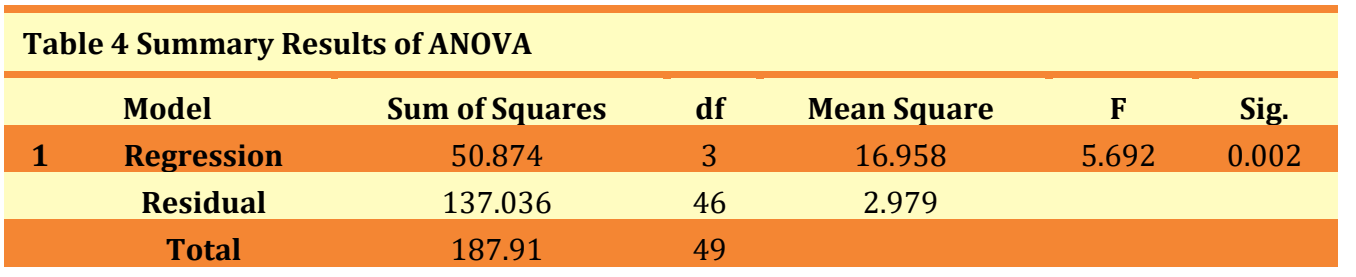

As we can see in Table 5, the contribution of EAR to the independent variables ROE was positive and significant (Beta $=.691 ; \mathrm{p}<.01$ ). In contrast, the contribution of the total debt and LAR were non-significant.

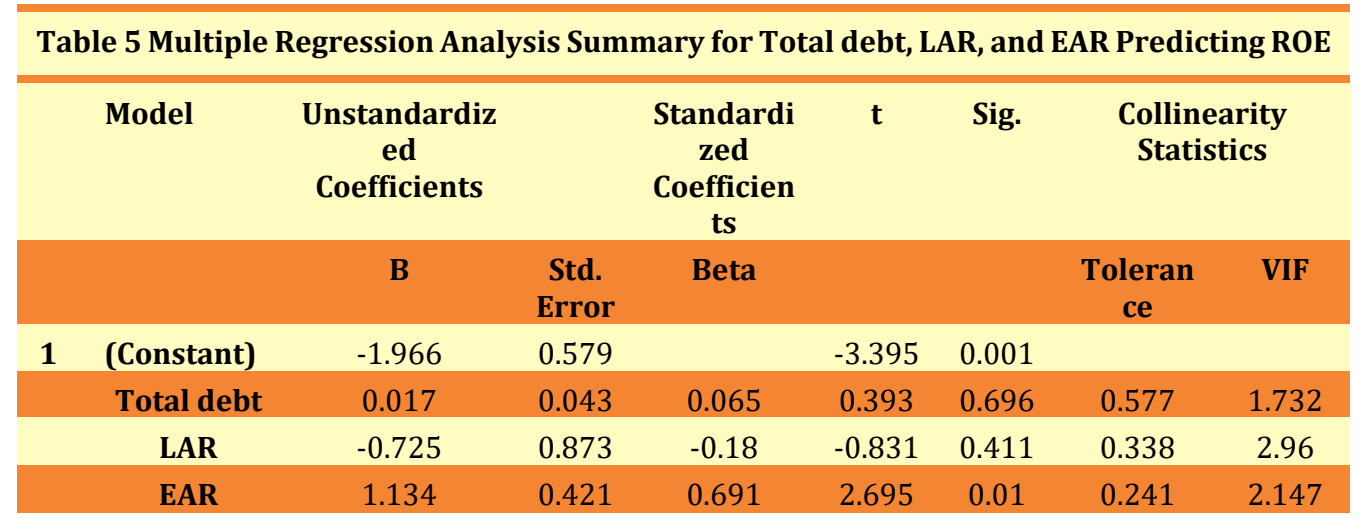

Multiple linear regression analysis was conducted to investigate the relative contribution of the predictors (independent variables) to the dependent variable, NPM. The model summary revealed that the model of the three independent variables explained $79 \%$ of the variance in NPM (R2 =.79). Results of ANOVA revealed that the model of total debt, LAR, and EAR was significantly predictor of NPM (Table 6). 


\begin{tabular}{|c|c|c|c|c|c|c|}
\hline \multicolumn{7}{|c|}{ Table 6 Summary Results of ANOVA } \\
\hline & Model & Sum of Squares & df & Mean Square & $\mathbf{F}$ & Sig. \\
\hline \multirow[t]{3}{*}{1} & Regression & 244.116 & 3 & 81.372 & 22.792 & 0 \\
\hline & Residual & 164.23 & 46 & 3.57 & & \\
\hline & Total & 408.346 & 49 & & & \\
\hline
\end{tabular}

As we can see in Table 7, the contribution of EAR to NPM was positive and significant (Beta=.982; $\mathrm{p}<.01$ ). In contrast, the contribution of the total debt and LAR were non-significant.

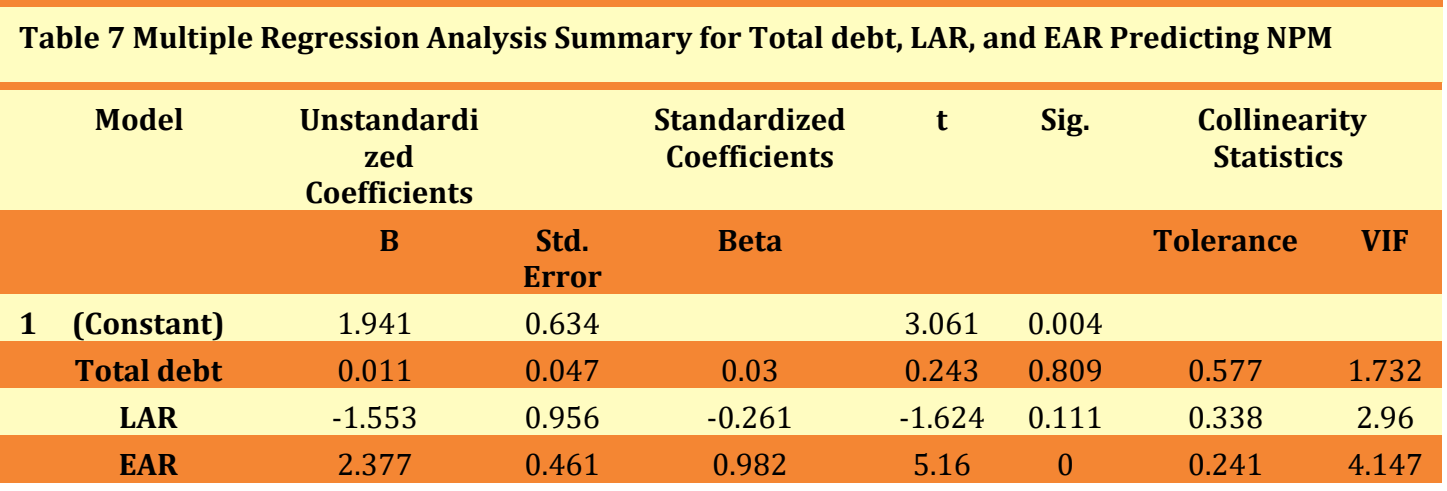

Multiple linear regression analysis was conducted to investigate the relative contribution of the predictors (independent variables) to the dependent variable, ROA. The model summary revealed that the model of the three independent variables explained $89 \%$ of the variance in ROA (R2 =.89). Results of ANOVA revealed that the model of total debt, LAR, and EAR was significantly predictor of ROA (Table 8).

\begin{tabular}{|c|c|c|c|c|c|c|}
\hline \multicolumn{7}{|c|}{ Table 8 Summary Results of ANOVA } \\
\hline & Model & Sum of Squares & df & Mean Square & $\mathbf{F}$ & Sig. \\
\hline \multirow[t]{3}{*}{1} & Regression & 0.572 & 3 & 0.191 & 356.775 & 0 \\
\hline & Residual & 0.025 & 46 & 0.001 & & \\
\hline & Total & 0.597 & 49 & & & \\
\hline
\end{tabular}

As we can see in Table 9, the contribution of the total debt to ROA was positive and significant (Beta $=.089 ; \mathrm{p}<.05$ ), the contribution of LAR to ROA was positive and significant (Beta=.439; $<<.01$ ), the contribution of the EAR to ROA was positive and significant (Beta=.639; $\mathrm{p}<.01$ ). In general, the contributions of the capital structure to ROA were positive and significant.

\begin{tabular}{|c|c|c|c|c|c|c|c|c|}
\hline & \multirow[t]{2}{*}{ Model } & \multirow{2}{*}{$\begin{array}{c}\text { Unstandardized } \\
\text { Coefficients } \\
\text { B }\end{array}$} & \multirow[b]{2}{*}{$\begin{array}{l}\text { Std. } \\
\text { Error }\end{array}$} & \multirow{2}{*}{$\begin{array}{c}\text { Standardized } \\
\text { Coefficients } \\
\text { Beta }\end{array}$} & \multirow[t]{2}{*}{$\mathbf{t}$} & \multirow[t]{2}{*}{ Sig. } & \multicolumn{2}{|c|}{$\begin{array}{c}\text { Collinearity } \\
\text { Statistics }\end{array}$} \\
\hline & & & & & & & Tolerance & VIF \\
\hline 1 & (Constant) & 0.144 & 0.008 & & 18.554 & 0 & & \\
\hline & Total debt & 0.001 & 0.001 & 0.089 & 2.267 & 0.028 & 0.577 & 1.732 \\
\hline & LAR & 0.1 & 0.012 & 0.439 & 8.519 & 0 & 0.338 & 2.96 \\
\hline & EAR & 0.059 & 0.006 & 0.639 & 10.488 & 0 & 0.241 & 4.147 \\
\hline
\end{tabular}


Third: The contributions of the independent variables on capital structure for the commercial banks sector

The Pearson product moment correlation coefficients were used to represent the relationship between the main independent variables (I.e., Total Debt, LAR, and EAR) and the dependent variables (ROA, ROE, NPM, EPS). Table 10 shows the correlation matrix that illustrates the interrelationships among the research variables.

\begin{tabular}{|ccccccccc}
\hline \multicolumn{7}{|c|}{ Table 10 Summary Results of Pearson Product Moment Correlation Coefficients } \\
\hline & ROE & ROA & NPM & EPS & Total debt & LAR & Kurtosis & Skewness \\
\hline ROE & 1 & & & & & & 1.187 & -0.605 \\
\hline ROA & $.449^{* *}$ & 1 & & & & 0.664 & 0.966 \\
\hline NPM & $.829^{* *}$ & $.562^{* *}$ & 1 & & & 0.249 & -0.735 \\
\hline EPS & 0.061 & $-.203^{*}$ & -0.168 & 1 & & & 1.197 & -0.605 \\
\hline Total debt & 0.109 & $-.367^{* *}$ & $-.207^{*}$ & $.191^{*}$ & 1 & & 0.566 & 0.589 \\
\hline LAR & -0.147 & $-.374^{* *}$ & $-.427^{* *}$ & $.213^{*}$ & $.505^{* *}$ & 1 & 0.249 & -0.735 \\
\hline EAR & -0.011 & $.487^{* *}$ & $.189^{*}$ & $-.216^{*}$ & $-.608^{* *}$ & $-.320^{* *}$ & -1.054 & -0.03 \\
\hline
\end{tabular}

It was observed that the total debt negatively and significantly related to ROA $(\mathrm{r}=-.367 ; \mathrm{p}<.01)$, NPM $(\mathrm{r}=-.207 ; \mathrm{p}<.05)$. In contrast, the total debt positively and significantly related EPS $(\mathrm{r}=.191 ; \mathrm{p}<.05)$. In contrast, the total debt does significantly relate to ROE.

LAR negatively and significantly related to ROA ( $\mathrm{r}=-.374 ; \mathrm{p}<.01)$, NPM ( $\mathrm{r}=-.427$; $\mathrm{p}<.01)$. Furthermore, LAR positively and significantly related to EPS ( $r=.213 ; \mathrm{p}<.05)$. In contrast, LAR does significantly relate to ROE.

Further, EAR positively and significantly related to ROA ( $\mathrm{r}=.487 ; \mathrm{p}<.01)$, NPM $(\mathrm{r}=.189 ; \mathrm{p}<.05)$. EAR negatively and significantly related to EPS $(\mathrm{r}=.216 ; \mathrm{p}<.05)$. In contrast, EAR does significantly relate to ROE.

Multiple linear regression analysis was conducted to investigate the relative contribution of the predictors (independent variables) to the dependent variable, EPS. The model summary revealed that the model of the three independent variables explained $26 \%$ of the variance in EPS (R2 =.26). Results of ANOVA revealed that the model of total debt, LAR, and EAR was significantly predictor of EPS (Table 11).

\begin{tabular}{|c|c|c|c|c|c|c|}
\hline \multicolumn{7}{|c|}{ Table 11 Summary Results of ANOVA } \\
\hline & Model & Sum of Squares & df & Mean Square & $\mathbf{F}$ & Sig. \\
\hline 1 & Regression & 77.412 & 3 & 25.804 & 2.908 & 0.038 \\
\hline & Residual & 1029.366 & 116 & 8.874 & & \\
\hline & Total & 1106.778 & 119 & & & \\
\hline
\end{tabular}

As we can see in Table 12, the contributions of the three independent variables to the EPS were non-significant.

\begin{tabular}{|c|c|c|c|c|c|c|}
\hline & \multirow[t]{2}{*}{ Model } & \multicolumn{2}{|l|}{$\begin{array}{l}\text { Unstandardized } \\
\text { Coefficients }\end{array}$} & \multirow{2}{*}{$\begin{array}{c}\text { Standardized } \\
\text { Coefficients } \\
\text { Beta }\end{array}$} & \multirow[t]{2}{*}{$\mathbf{t}$} & \multirow[t]{2}{*}{ Sig. } \\
\hline & & B & $\begin{array}{l}\text { Std. } \\
\text { Error }\end{array}$ & & & \\
\hline 1 & (Constant) & 1.641 & 0.83 & & 1.978 & 0.05 \\
\hline & Total debt & 0.006 & 0.037 & 0.02 & 0.16 & 0.873 \\
\hline
\end{tabular}




$\begin{array}{lccccc}\text { LAR } & 1.191 & 0.805 & 0.153 & 1.479 & 0.142 \\ \text { EAR } & -0.627 & 0.456 & -0.155 & -1.374 & 0.172\end{array}$

Multiple linear regression analysis was conducted to investigate the relative contribution of the predictors (independent variables) to the dependent variable, ROE. The model summary revealed that the model of the three independent variables explained $27 \%$ of the variance in ROE (R2 =.27). Results of ANOVA revealed that the model of total debt, LAR, and EAR was significantly predictor of ROE (Table 13).

\begin{tabular}{|c|c|c|c|c|c|c|}
\hline \multicolumn{7}{|c|}{ Table 13 Summary Results of ANOVA } \\
\hline & Model & Sum of Squares & df & Mean Square & $\mathbf{F}$ & Sig. \\
\hline 1 & Regression & 7.726 & 3 & 2.575 & 2.938 & 0.036 \\
\hline & Residual & 101.696 & 116 & 0.877 & & \\
\hline & Total & 109.423 & 119 & & & \\
\hline
\end{tabular}

As we can see in Table 14, the contribution of total debt to the independent variables ROE was positive and significant (Beta $=.295 ; \mathrm{p}<.05)$ and the contribution of the LAR to the independent variables ROE was positive and significant (Beta=.209; $\mathrm{p}<.05$ ). In contrast, the contribution of the EAR to the independent variables ROE was non-significant.

\begin{tabular}{|c|c|c|c|c|c|c|}
\hline & \multirow[t]{2}{*}{ Model } & \multirow{2}{*}{$\begin{array}{c}\text { Unstandardized } \\
\text { Coefficients } \\
\text { B }\end{array}$} & & \multirow{2}{*}{$\begin{array}{c}\text { Standardized } \\
\text { Coefficients } \\
\text { Beta }\end{array}$} & \multirow[t]{2}{*}{$\mathbf{t}$} & \multirow[t]{2}{*}{ Sig. } \\
\hline & & & $\begin{array}{l}\text { Std. } \\
\text { Error }\end{array}$ & & & \\
\hline 1 & (Constant) & -2.58 & 0.261 & & -9.891 & 0 \\
\hline & Total debt & 0.028 & 0.012 & 0.295 & 2.382 & 0.019 \\
\hline & LAR & -0.656 & 0.253 & 0.269 & 2.593 & 0.011 \\
\hline & EAR & 0.105 & 0.143 & 0.083 & 0.734 & 0.464 \\
\hline
\end{tabular}

Multiple linear regression analysis was conducted to investigate the relative contribution of the predictors (independent variables) to the dependent variable, NPM. The model summary revealed that the model of the three independent variables explained $43 \%$ of the variance in NPM (R2 =.43). Results of ANOVA revealed that the model of total debt, LAR, and EAR was significantly predictor of NPM (Table 15).

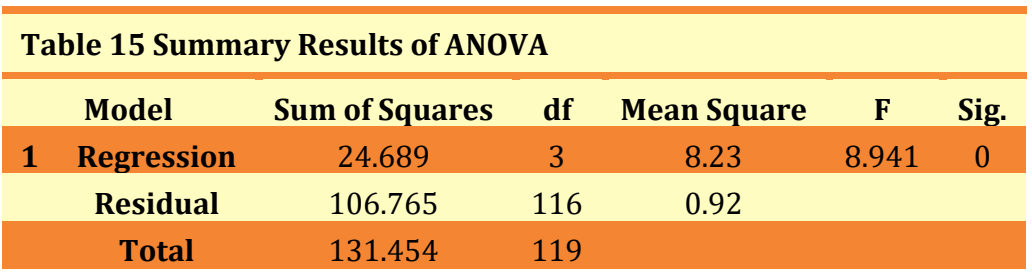

As we can see in Table 16, the contribution of the LAR to NPM was positive and significant (Beta=.432; $\mathrm{p}<.01$ ). In contrast the contributions of the EAR and the total debt to NPM were non-significant. 


\begin{tabular}{|c|c|c|c|c|c|c|}
\hline & \multirow[t]{2}{*}{ Model } & \multicolumn{2}{|l|}{$\begin{array}{l}\text { Unstandardized } \\
\text { Coefficients }\end{array}$} & \multirow{2}{*}{$\begin{array}{c}\text { Standardized } \\
\text { Coefficients } \\
\text { Beta }\end{array}$} & \multirow[t]{2}{*}{$\mathbf{t}$} & \multirow[t]{2}{*}{ Sig. } \\
\hline & & $\mathbf{B}$ & $\begin{array}{l}\text { Std. } \\
\text { Error }\end{array}$ & & & \\
\hline 1 & (Constant) & -1.464 & 0.267 & & -5.479 & 0 \\
\hline & Total debt & 0.007 & 0.012 & 0.067 & 0.581 & 0.562 \\
\hline & LAR & -1.155 & 0.259 & 0.432 & 4.452 & 0 \\
\hline & EAR & 0.128 & 0.147 & 0.092 & 0.87 & 0.386 \\
\hline
\end{tabular}

Multiple linear regression analysis was conducted to investigate the relative contribution of the predictors (independent variables) to the dependent variable, ROA. The model summary revealed that the model of the three independent variables explained $54 \%$ of the variance in ROA (R2 =.54). Results of ANOVA revealed that the model of total debt, LAR, and EAR was significantly predictor of ROA (Table 17).

\begin{tabular}{|c|c|c|c|c|c|c|}
\hline \multicolumn{7}{|c|}{ Table 17 Summary Results of ANOVA } \\
\hline & Model & Sum of Squares & df & Mean Square & $\mathbf{F}$ & Sig. \\
\hline 1 & Regression & 0.024 & 3 & 0.008 & 15.796 & 0 \\
\hline & Residual & 0.059 & 116 & 0.001 & & \\
\hline & Total & 0.083 & 119 & & & \\
\hline
\end{tabular}

As we can see in Table 18, the contribution of the LAR to ROA was positive and significant (Beta $=.246 ; \mathrm{p}<.05$ ), the contribution of EAR to ROA was positive and significant (Beta=.413; $\mathrm{p}<.01$ ), the contribution of the total debt to ROA was nonsignificant). In general, the contributions of the LAR and EAR to ROA were positive and significant.

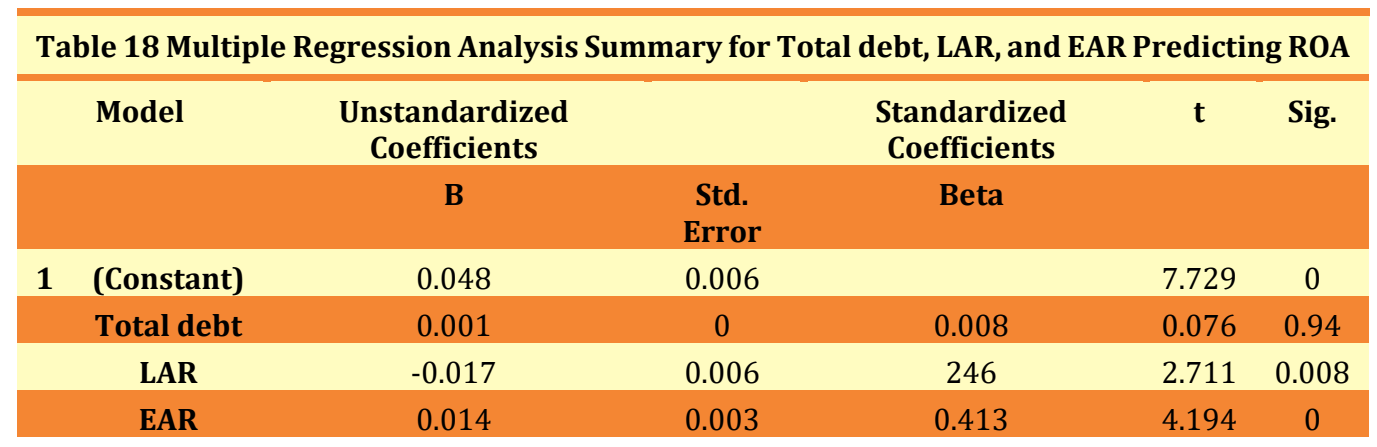

\section{CONCLUSION \\ 7.1 FOR THE ISLAMIC BANKS SECTOR}

It was observed that the total debt negatively and significantly related to ROE, NPM, and ROA. This means that ROE, NPM, and ROA increase as the total debt decreases. In contrast, total debt positively and significantly related to EPS. As such, EPS increases as the total debt increases. LAR positively and significantly related to ROA, NPM, and ROE. This means that ROE, NPM, and ROA increase as the LAR increase. In contrast, LAR negatively and significantly related to EPS. This means that EPS increases as LAR decreases. EAR positively and significantly related to ROE, ROA, and NPN. This means that ROE, NPM, and ROA increase as the EAR increase in 
contrast, EAR negatively and significantly related to EPS. This means that EPS increases as EAR decreases. Regression analysis revealed that EAR was a significant predictor of ROE and NPM. Furthermore, the contributions of the capital structure to ROA were significant. In this study, the total debt negatively and significantly related to ROE, NPM, and ROA. Similarly, LAR and EAR are negatively and significantly related to EPS. Further, the results of the present study revealed that the contributions of the capital structure to ROA were significant.

\subsection{FOR THE COMMERCIAL BANKS SECTOR}

It was observed that the total debt negatively and significantly related to ROA and NPM. This means that ROA and NPM increase as the total debt decreases. Further, the total debt positively and significantly related to EPS. This means EPS increases as the total debt increases. In contrast, the total debt does not significantly relate to ROE. LAR negatively and significantly related to ROA, NPM. This means that ROA and NPM increase as LAR decrease. Furthermore, LAR positively and significantly related to EPS. This means that EPS increases as LAR increases. In contrast, LAR does not significantly relate to ROE. Further, EAR positively and significantly related to ROA and NPM. This means that ROA increases as EAR increases. Further, EAR negatively and significantly related to EPS. This means that EPS increases as EAR decreases in contrast, EAR does not significantly relate to ROE. Further, the regression analysis revealed that the contributions of the three independent variables to the EPS were non-significant. Also, the contributions of the total debt and LAR to the independent variables ROE were significant. In contrast, the contribution of the EAR to the independent variable ROE was non-significant. Moreover, the contribution of the LAR to NPM was significant. Also, the contributions of the EAR and the total debt to NPM were non-significant. Furthermore, the contributions of the LAR and EAR to ROA were significant. In contrast, the contribution of the total debt to ROA was non-significant. In general, the contributions of the LAR and EAR to ROA were significant.

\section{REFERENCES}

Ali, M. (2018). Determining the Factors of Profitability in Islamic and Conventional Banks of Pakistan; a Management Perspective. SEISENSE Journal of Management, 1 (1), 8-21. Retrieved from https://journal.seisense.com/index.php/jom/article/view/1

El-Chaarani1, H, \& El-Abiad, Z. (2019). Analysis of Capital Structure and Performance of Banking Sector in Middle East Countries. International Journal of Economics and Financial Issues, 9(2), 1-11. Retrieved from https://papers.ssrn.com/sol3/papers.cfm?abstract_id=3845068

Hai Dang, Y. T., Hong Bui, N., Anh Thi Hoang Dao, A.T., \& Nguyen, H.T. (2019). THE IMPACT OF CAPITAL STRUCTURE ON FIRM PERFORMANCE - EMPIRICAL EVIDENCE FROM LISTED FOOD AND BEVERAGE COMPANIES IN VIETNAM. International Journal of Economics, Commerce and Management, Vol. VII, Issue 2, 567-577

Li, K., Niskanen, J. \& Niskanen, M. (2019), "Capital structure and firm performance in European SMEs : Does credit risk make a difference ?", Managerial Finance, Vol. 45 No. 5, pp. 582-601. Retrieved from https://doi.org/10.1108/MF-01-2017-0018

Meero, A.A. (2015). The Relationship between Capital Structure and Performance in Gulf Countries Banks:A Comparative Study between Islamic Banks and 
Conventional Banks. International Journal of Economics and Finance, 7 (12), 140-154. Retrieved from https://doi.org/10.5539/ijef.v7n12p140

Ramli, N. A., Latan, H., \& Solovida, G. T. (2018). Determinants of capital structure and firm financial performance-A PLS-SEM approach: Evidence from Malaysia and Indonesia. The Quarterly Review of Economics and Finance. Retrieved from https://doi.org/10.1016/j.qref.2018.07.001

Sakr, A. \& Bedeir, A. (2019). Impact of Capital Structure on Firm's Performance : Focusing on Non-financial Listed Egyptian Firms. International Journal of Financial Research, 6(10), 78-87. Retrieved from https://doi.org/10.5430/ijfr.v10n6p78

Sheikh, N. A. \& Qureshi, M. A. (2017). Determinants of capital structure of Islamic and conventional commercial banks : Evidence from Pakistan. International Journal of Islamic and Middle Eastern Finance and Management, 10(1), 2441. Retrieved from https://doi.org/10.1108/IMEFM-10-2015-0119

Sivalingam, L., \& Kengatharan, L. (2018). Capital Structure and Financial Performance : A Study on Commercial Banks in Sri Lanka. Asian Economic and Financial Review, 8(5) : Retrieved from https://doi.org/10.18488/journal.aefr.2018.85.586.598

A, O. V. A. M. (2018). Capital Structure and Its Impact on Profitability of IFCI Ltd : An Empirical Analysis. International Journal of Latest Engineering and Management Research (IJLEMR), 3 (6), 84-90 